\section{BA Institute of \\ yk Business Administration \\ तर Karachi \\ Leadership and Ideas for Tomorrow}

Article 16

Volume 1 Issue 1

July - December 2006

7-1-2006

\title{
Have we missed the rally?
}

Talib Haider

Geo T.V

Follow this and additional works at: https://ir.iba.edu.pk/businessreview

Part of the Economics Commons

(c) (i)

This work is licensed under a Creative Commons Attribution 4.0 International License.

\section{Recommended Citation}

Haider, T. (2006). Have we missed the rally?. Business Review, 1(1), 191-194. Retrieved from https://doi.org/10.54784/1990-6587.1104

This article is brought to you by iRepository for open access under the Creative Commons Attribution 4.0 License and is available at https://ir.iba.edu.pk/businessreview/vol1/iss1/16. For more information, please contact irepository@iba.edu.pk. 


\title{
FACT FILE
}

\section{Have we missed the rally?}

\author{
Talib Haider
}

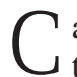
apital Markets across the world have made many rich and many poor. Though the number of people losing money appears to be somewhat more, this notion simply becomes relative if one looks at it from stock investment perspective, where one loses one day and gains on another.

KSE-100 index, the prime index in Pakistan, has been one of the best performing markets in the world. In just two years, the index has gained almost 8,000 points and market capitalization has crossed $\$ 55$ billion.

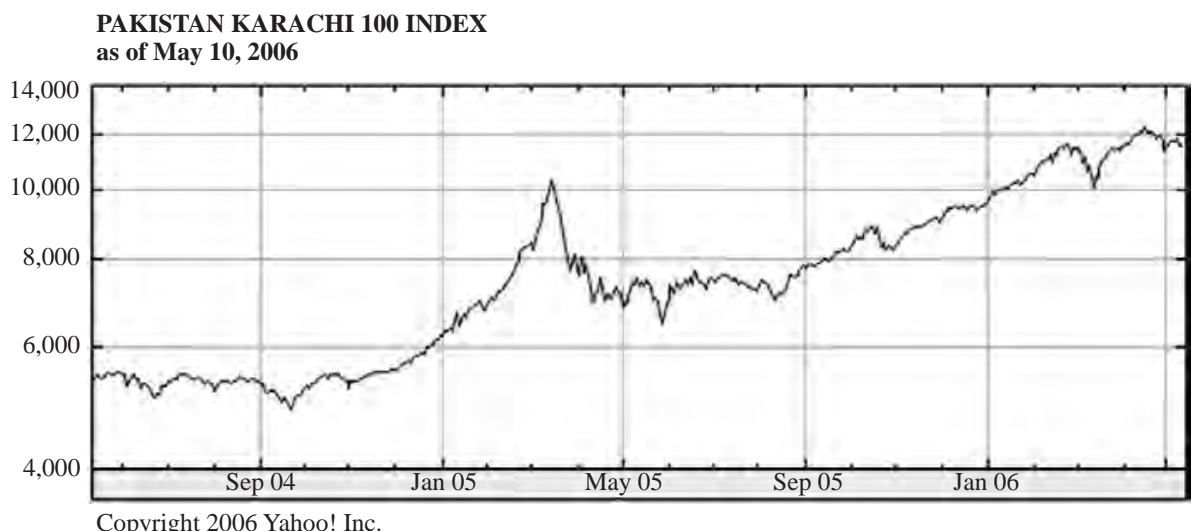

The index gained through many factors that drove the market to new levels in just a small period. When the index started moving upwards at a very high pace in 20032004, many thought that it was simply a bubble, which will, like any other artificial boom, burst soon and similar situation of the stock market, like the one when the government had a nuclear test, resulted in the stock market taking a nosedive and touching all time low of less than 800 points, will occur. But this does not seem to be the case in the recent growth. Following are some of the major factors that have driven the KSE-100 to new heights:

\section{PRIVATIZATION FOR PEOPLE}

The process of privatization which again gained momentum with the new government deciding to privatize the state-owned entities and use the inflows to reduce poverty and improve infrastructure. The privatization process became the main driver of the stock market; every news directly or indirectly fuelling the market. The share of the 
companies to be privatized came into lime light. Massive activity thus started at KSE, where the average volumes improved and the investors' interest developed.

Privatization of PTCL and PSO has been the major trigger for the market. The news about the PTCL privatization remained in the limelight till Etisalat finally won the bid and took over as the new manager of the telecom giant. As of now, the management is transferred to the new employers though no development plans by the company have been announced yet.

Privatization of PSO which became lackluster after many delays by the privatization body, is now picking up pace as Prime Minister of Pakistan Shaukat Aziz has reportedly said that PSO's privatization will be completed by August' 06.

\section{The Information Age}

One of the major factors in this case is the growth of Media industry. With "freedom to media" slogan by the current government, many TV channels opened and gave the viewers a new world of information which they were deprived of since decades.

For the stock market investors, who used to wait for their brokers to give information about scrip expected to perform better, commonly known as a "tip", the starting of live shows covering the market became an instant hit. Everyday, these stock market programs started covering Big brokers, who were supposed to have the best information about the market and also were inaccessible to small investor, gave their views on the expectations of market going for a "Tezi ( market going up aka Bulls)" or "Mandee (market going down aka Bears)". Analysts were viewed giving reasons for a scrip about to make a mark on the index or how double digit profits are likely to be achieved. The increased supply of information resulted in massive interest in the business circles or with people who possessed millions but did not know where to invest; stock market thus witnessed many new investors entering the new investment arena.

\section{PAKISTAN: NEW COUNTRY ON THE WORLD'S MAP}

In the last five years, the economic growth has been the pride of the government with GDP growth rate touching $8.35 \%$ in the year 2004-2005. Some of the major indicators highlighting the economic performance are provided below:

\begin{tabular}{|l|c|c|c|c|}
\hline Indicators & FY 02 & FY 03 & FY 04 & FY 05 \\
\hline GDP Growth & $3.1 \%$ & $5.1 \%$ & $6.4 \%$ & $8.35 \%$ \\
\hline FDI (\$, million) & 484.70 & 798 & 949 & 1,524 \\
\hline Import (\$, billion) & 10.34 & 12.22 & 15.59 & 20.62 \\
\hline Export (\$, billion) & 9.14 & 11.16 & 12.31 & 14.41 \\
\hline Workers' Remittances (\$, bn) & 2.34 & 4.19 & 3.83 & 4.17 \\
\hline Forex Reserves (\$, bn) & 6.43 & 10.72 & 12.33 & 12.61 \\
\hline
\end{tabular}


The economic performance has been driven by growth in large scale manufacturing sector with service sector also going for better performance. In case of stock market, all the major sectors performed extremely well and registered huge gains, thus giving investors more incentives to continue investing in the stock market.

\section{KSE-100 index listed sectors' performance in 2005}

\section{Market Capitalization change in 2005}

\begin{tabular}{|r|l|r|}
\hline S.No. & \multicolumn{1}{|c|}{ Sector } & \% Chg \\
\hline 1 & Commercial Banks & $200 \%$ \\
\hline 2 & Cement & $86 \%$ \\
\hline 3 & O\&G Exploration & $54 \%$ \\
\hline 4 & Refinery & $53 \%$ \\
\hline 5 & Transport & $53 \%$ \\
\hline 6 & Power Generation & $51 \%$ \\
\hline 7 & Tech. \& Comm. & $51 \%$ \\
\hline 8 & O\&G Marketing & $46 \%$ \\
\hline 9 & Insurance & $45 \%$ \\
\hline 10 & Cable \& Elec. Goods & $44 \%$ \\
\hline 11 & Auto Assembler & $41 \%$ \\
\hline 12 & Jute & $40 \%$ \\
\hline 13 & Fertilizer & $39 \%$ \\
\hline 14 & Investment Banks & $37 \%$ \\
\hline 15 & Close-end-Mutual F. & $31 \%$ \\
\hline 16 & F \& P Care Products & $31 \%$ \\
\hline 17 & Sugar \& Allied Ind. & $30 \%$ \\
\hline
\end{tabular}

\begin{tabular}{|c|l|r|}
\hline S.No. & \multicolumn{1}{|c|}{ Sector } & \% Chg \\
\hline 18 & Miscellaneous & $29 \%$ \\
\hline 19 & Engineering & $24 \%$ \\
\hline 20 & Textile Composite & $23 \%$ \\
\hline 21 & Paper \& Board & $15 \%$ \\
\hline 22 & Pharmaceuticals & $13 \%$ \\
\hline 23 & Leather \& Tanneries & $9 \%$ \\
\hline 24 & Tobacco & $8 \%$ \\
\hline 25 & Leasing Companies & $7 \%$ \\
\hline 26 & Textile Weaving & $7 \%$ \\
\hline 27 & Chemicals & $4 \%$ \\
\hline 28 & Modarabas & $-1 \%$ \\
\hline 29 & Auto Parts \& Access. & $-3 \%$ \\
\hline 30 & Glass \& Ceramics & $-11 \%$ \\
\hline 31 & Textile Spinning & $-16 \%$ \\
\hline 32 & Synthetic \& Rayon & $-18 \%$ \\
\hline 33 & Vanaspati \& Allied Ind. & $-24 \%$ \\
\hline 34 & Woolen & $-25 \%$ \\
\hline
\end{tabular}

\section{International Oil Prices}

KSE-100 index is highly skewed towards oil sector. E\&P sector constitutes more than $30 \%$ of the index. With such a weight linked to oil, changes in oil prices have a major impact on the index. Internationally, in just two years, the oil price has almost increased by $100 \%$ touching $\$ 75 /$ barrel recently. The prices have resulted in oil and gas exploration companies to increase their search for black gold. Though the cost of imports has shot up and is hurting the economy, the increase in oil prices is positive for the stock market. 
E\&P sector price performance on KSE-100 in the last 2 years:

\begin{tabular}{|l|r|r|r|r|}
\hline \multicolumn{1}{|c|}{ SCRIP } & \multicolumn{1}{c|}{$\begin{array}{c}\text { 30th Jan - 04 } \\
\text { (Price, Rs.) }\end{array}$} & $\begin{array}{c}\text { 3rd Jan - 05 } \\
\text { (Price, Rs.) }\end{array}$ & $\begin{array}{c}\text { 2nd Jan - 06 } \\
\text { (Price, Rs.) }\end{array}$ & \multicolumn{1}{c|}{$\begin{array}{c}\text { 1st April - 06 } \\
\text { (Price, Rs.) }\end{array}$} \\
\hline OGDC & 53.75 & 74.35 & 118.25 & 156.9 \\
\hline POL & 225.45 & 246.00 & 429.15 & 642.00 \\
\hline PPL & - & 141.10 & 210.35 & 275.00 \\
\hline KSE-100 & $4,841.33$ & $6,220.28$ & $9,672.47$ & $11,573.94$ \\
\hline
\end{tabular}

\section{KSE-100 - The Current Scenario}

After evaluating the factors just mentioned, one can depict that the stock market boom is simply not a bubble about to burst, rather an actual growth story based on strong economic development in the country as well as growth of the capital market itself.

But will this growth be able to sustain? Lets look at the current issues prevailing in the market:

- $\quad$ After the major tussle between SECP (the regulators) and KSE (management), we are now seeing KSE board which for the first time in history has a Non-broker Chairman. The board is expected to initiate new projects and plans for market development

- International oil prices are again sky rocketing, with NYMEX crude oil price touching the $\$ 75 /$ barrel mark.

- Privatization of several public entities has been completed yet there are other companies still in the pipeline: PSO, SNGPL, SLIC, SSGC, etc.

- The government is targeting 6-7\% GDP growth rate for the next five years.

- $\quad$ Current account deficit of the nation is soaring towards \$7-9bn for FY06.

- $\quad \mathrm{KSE}-30$ index is on the cards, but its launch seems to be getting delayed and likely to come in the market by July '06.

- $\quad$ CFS is to be replaced by a new product, which is expected to carry no financing cap and is likely to provide more liquidity to the investors.

Capital markets in Pakistan are now entering a new era with many players in the market, lots of new individuals putting their savings in this investment avenue. With so much growth happening, so many individuals getting hefty profits, one believes that growth of this industry is inevitable and the index will touch new heights, but with several index crashes in the past, one simply cannot be totally sure about its future outlook. 